Tropical Journal of Pharmaceutical Research December 2013; 12 (6): 1107-1112

ISSN: $1596-5996$ (print); 1596-9827 (electronic)

(C) Pharmacotherapy Group, Faculty of Pharmacy, University of Benin, Benin City, 300001 Nigeria.

All rights reserved.

Available online at http://www.tjpr.org

Review Article

http://dx.doi.org/10.4314/tjpr.v12i6.36

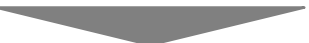

\title{
State of Pharmacy Education in Bangladesh
}

\author{
Gazi Mahabubul Alam ${ }^{1 *}$, Mirja Mohammad Shahjamal ${ }^{2}$, Abul Quasem Al-Amin $^{3}$ \\ and Mohammad Nurul Azam ${ }^{4}$ \\ ${ }^{1}$ Academic Performance Enhancement Unit, University of Malaya, 50603 Kuala Lumpur, Malaysia, ${ }^{2}$ British Council, 5 Fuller \\ Road, Dhaka, Bangladesh, ${ }^{3}$ Faculty of Economics and Administration, University of Malaya, Malaysia, ${ }^{4}$ Department of \\ Quantitative Analysis, College of Business Administration, King Saud University, Riyadh 11451, Kingdom of Saudi Arabia.
}

*For correspondence: Email: gazimalamb@yahoo.com

\begin{abstract}
The current state of pharmacy education in Bangladesh and identification of the current gaps in terms of manpower development for the pharmaceutical sector are described in this paper.

Information for the preparation of this paper was obtained from documents and interviews of stakeholders drawn from regulatory, industrial and educational agencies. Three levels of pharmacy education is currently offered in Bangladesh leading to either a university degree, a diploma or a certificate. Graduates with degrees work in industry while those with diplomas work in hospitals. Thus, hospitals are not benefiting from the training of pharmacy graduates just like community pharmacies that employ those with certificates. This situation is encouraged by lack of prescribed minimum standards required for the training of practitioners and practice of pharmacy in Bangladesh. Conflict of regulatory roles in the training of those with diplomas does exist. The state of pharmacy education in Bangladesh is less than satisfactory. A proper regulatory framework that ensures quality training of pharmaceutical manpower is lacking. Community and hospital pharmacies, therefore, have an unmet need in terms of the skill of the staff that operates them. The situation is further encouraged by the absence of minimum standards requirements for pharmacy practice.
\end{abstract}

Keywords: Pharmacy education, Community pharmacists, National development, Public and Private Sectors, Policy.

Tropical Journal of Pharmaceutical Research is indexed by Science Citation Index (SciSearch), Scopus, International Pharmaceutical Abstract, Chemical Abstracts, Embase, Index Copernicus, EBSCO, African Index Medicus, JournalSeek, Journal Citation Reports/Science Edition, Directory of Open Access Journals (DOAJ), African Journal Online, Bioline International, Open-J-Gate and Pharmacy Abstracts

\section{INTRODUCTION}

Delivery of Pharmacy Education in Bangladesh started with the provision of higher education supported by regulatory agencies and professional bodies in order to ensure proper quality assurance [1]. In order to ensure socioeconomic development, many countries that provide Pharmacy Education do so by having different types of programmes and courses leading to the award of a diploma or degrees [2]. Thus, different skilled levels of pharmaceutical manpower that can meet the needs of the industry in terms of drug discovery, manufacturing, distribution and dispensing were produced [3].

Pharmacy Education in many developing countries, including Bangladesh, is still limited to didactic learning that produce theoretically 'skilled' professionals with degrees [4]. Manpower development for community pharmacies in Bangladesh is not systematically regulated and constitute an important public health issue[5]. While critics blame the stakeholders involved in the sector of Pharmacy 
Education for these shortfalls, adherents argue that Pharmacy Education does not live in isolation; it is therefore an overall national shortcoming and constraints that are responsible $[6,8,16]$.

Literature evidence $[9,10]$ has it that while Pharmacy Education in Bangladesh contributes reasonably to economic development, contribution to social development is insignificant since it lacks community pharmacists $[7,8]$. Therefore, the aim of this report is to present the state of pharmacy education in Bangladesh and identify the gaps in terms of quality manpower development for the pharmaceutical sector.

\section{SETTING}

This analysis of the state of pharmacy education was carried out in Bangladesh where lack of political will has failed in ensuring qualitative health care service provision despite an increasing number of healthcare facilities. There exist shortage of skilled healthcare manpower and weak institutional management. The private sector usually employs those working in the public sector on part-time basis thereby weakening the commitment of the public service employees.

\section{Data sources and collection}

Information for this paper were obtained from documents and semi-structured qualitative discussion with stakeholders (such as students, regulators, academics, legislators, industry leaders and pharmacy practitioners) over a two weeks period drawn from government agencies such as: Bangladesh Ministry of Health and family planning, Drug administration, Pharmaceutical Society, Technical Education Board and Pharmacy Council of Bangladesh. Others were obtained from the Pharmaceutical industry and both public and private universities. Some of the interviews were recorded and later transcribed and used as part of the information that describes the state of pharmacy education in Bangladesh.

\section{Data Analysis}

The information obtained from the different documents and recorded interviews were used to describe the state of pharmacy education in Bangladesh. The public and private universities have been tabulated (table 1 and 2).

\section{Initiation of pharmacy education}

Without an official recognition of pharmacy as a profession, Dhaka University (DU) under the regime of Pakistan started offering Pharmacy as a course in 1964 [6]. The department of Pharmacy was leter upgraded into a faculty. After one year of the graduation of the first batch, in 1969, DU started offering Master's programme [6]. The duration of initially offered undergraduate programme was 3 years which was later extended to four years in 1996 [6-7]. In a bid to have international acceptance, the undergraduate programme was further extended to five years. However, the old curriculum was not revised hence, the one year extension failed to achieve full international accreditation [7]. Therefore, Pharmacy graduates from universities in Bangladesh are not allowed to sit for pharmacy registration examinations in many countries especially in the USA [7]. In the late 1980s to1990s, three more public universities started offering pharmacy [6]. Recently, an, additional three more public universities and twenty two private universities have started working in the area of Pharmacy Education provision with questionable quality (Table 1). The overall quality of pharmacy education in Bangladesh is debateable compared to other countries' international standard. Pharmacy education offered by private universities is done in the absence of proper infrastructure and a properly moderated curriculum supervised by regulatory agencies as done in other countries. it seems the institutions are responding to the high demands for pharmacy education by the citizens without proper federal planning for socioeconomic development.[6]. Both public and private universities offer bachelor and master's degree programmes.

According to Pharmacy Council of Bangladesh [12], three public and thirty one private institutions also offer a three-year diploma programmes. Reports $[3,4]$ have it that pharmacy training in the universities produce pharmaceutical manpower for the drug manufacturing industries while there students whose training stopped at the diploma level were to work as semi-skilled personnel in industry and hospitals $[6,12]$. There is no provision in place to produce skilled community pharmacists [8]. Government regulation does not have a minimum standard requirement for those who retail drugs to members of the public. This has negative health implications for the society. 
Table 1: Public universities offering pharmacy with location and intake capacity of courses

\begin{tabular}{|c|c|c|c|c|c|}
\hline SI. & Name of University & Location & $\begin{array}{l}\text { Year } \\
\text { established }\end{array}$ & $\begin{array}{l}\text { Enrolment } \\
\text { capacity per } \\
\text { year }\end{array}$ & $\begin{array}{l}\text { Type of } \\
\text { accreditation by } \\
\text { PBC/PCB }\end{array}$ \\
\hline 1. & University of Dhaka & Dhaka & 1964 & 70 & Permanent \\
\hline 2. & University of Jahangirnagar & Savar, Dhaka & 1985 & 55 & Permanent \\
\hline 3. & University of Rajshahi & Rajshahi & 1990 & 45 & Permanent \\
\hline 4. & University of Khulna & Khulna & 1997 & 37 & Temporary \\
\hline 5. & $\begin{array}{l}\text { Noakhali Science and } \\
\text { Technology University }\end{array}$ & Noakhali & 2006 & 50 & Temporary \\
\hline 6. & Jagannath University & Dhaka & 2009 & 20 & Temporary \\
\hline 7. & University of Jessore & Jessore & 2010 & $-?$ & Temporary \\
\hline
\end{tabular}

Source: Data compiled from University Grants Commission (UGC) and Pharmacy Council of Bangladesh (PCB) $[3,11]$

academics from public institutions are engaged as part-time lecturers in private universities.. Although the UGC and PCB have been trying to upgrade pharmacy education in Bangladesh, there is still a lot to be accomplished.

\section{Diploma and Certificates in pharmacy}

The PCB also regulates a 3-year diploma of pharmacy course. Three public Institutes have been offering a 3-year diploma programme in Pharmacy. Two of these are located in Dhaka and one of them is operated by the 'Armed Forces of Bangladesh (Table-3).A number of private institutions are also offering a 3-year diploma in pharmacy (Table-3). Those with Secondary School Certificate (SSC) in the sciences are eligible for admission into the diploma in pharmacy programme. These diploma graduates obtain ' $\mathrm{B}$ ' grade registration directly from PCB. No additional examination is required for this registration because PCB directly regulates the curriculum and examinations of the diploma programme.

In addition, PCB also regulates pharmacy certificate courses. Those, who have passed SSC examination can take a 3-month special certificate courses designed and jointly conducted by Bangladesh Pharmaceutical Society (BPS) and Bangladesh Chemists and Druggists Society (BCDS). Those who pass these certificate examinations are categorized as ' $C$ ' grade pharmacists by PCB and they usually work in community pharmacies or run their own pharmacies .However, since there is no compulsory minimum standard requirement in terms of qualification and knowledge to be able to work as a technician in a pharmacy; anyone hardly takes this programme. This certificate lacks practical exposure.

\section{REGULATION OF TERTIARY PHARMACY EDUCATION}

Universities in Bangladesh are approved by the University Grants Commission (created by the Presidential Order- P.O. No 10 of 1973 of the Government of the Peoples' Republic of Bangladesh). However, in order to offer professional programmes, a simple approval from the UGC is not sufficient. Universities also need to comply by the regulatory quidelines prescribed by the respective government agencies and professional bodies. Since pharmacy is a professional subject, the Government of the People's Republic of Bangladesh promulgated the Pharmacy Ordinance (No. X111) in 1976 and set up the Pharmacy Council of Bangladesh (PCB) under the Ministry of Health and Family Welfare. Since then the pharmacy courses are designed and controlled by the PCB. To ensure quality teaching and to meet the high professional standard required of pharmacists, PCB initiated 'A grade' registration examination system for pharmacy graduates of different universities in 2005. Pharmacists having ' $A$ ' grade registration are eligible to practice pharmacy within the country.

\section{Regulation of diploma in pharmacy}

Theoretically, by the virtue of the Technical Education Act-1967, diploma level education is offered by polytechnics or polytechnic level institutions with affiliation and approval provided by the Bangladesh Technical Education Board (BTEB). According to the BTEB, on the basis of current legislative framework, diploma qualifications cannot be offered by any provider and regulatory body or professional agency without the approval 
Table 3: Public and Private Institutes offering Diploma in Pharmacy with location

\begin{tabular}{|c|c|c|c|c|c|}
\hline SN & Name & Location & $(\mathrm{SN})$ & Name & Location \\
\hline \multicolumn{3}{|c|}{ a) Public } & 14 & TMSS Medical Technology Institute & Bogra \\
\hline 1 & Institute of Health Technology & Dhaka & 15 & Rumdu Institute of Health Technology & Mymensingh \\
\hline 2 & Institute of Health Technology & Rajshahi & 16 & Institute of Medical Technology & Faridpur \\
\hline 3 & Armed Forces Medical Institutes & Dhaka & 17 & Shaheed SA Memorial Medicallnstitute & Dhaka \\
\hline \multicolumn{3}{|c|}{ b) Private } & 18 & Institute of Medical Technology & Rajbari \\
\hline 1 & $\begin{array}{l}\text { Bangladesh Institute of Medical and } \\
\text { Dental Technology }\end{array}$ & Dhaka & 19 & $\begin{array}{l}\text { Fortune Institute of Health } \\
\text { Technology }\end{array}$ & Dhaka \\
\hline 2 & $\begin{array}{l}\text { National Institute of Medical and Dental } \\
\text { Technology }\end{array}$ & Dhaka & 20 & $\begin{array}{l}\text { Prince Institute of Medical } \\
\text { Technology }\end{array}$ & Dhaka \\
\hline 3 & International Institute of Health Science & Dhaka & 21 & $\begin{array}{l}\text { Rajshahi Institute of Medical } \\
\text { Technology }\end{array}$ & Rajshahi \\
\hline 4 & Psyche Institute of Medical Technology & Dhaka & 22 & Prime Institute of Medical Technology & Rajshahi \\
\hline 5 & Marks Institute of Medical Technology & Dhaka & 23 & Dhaka Institute of Health Technology & Dhaka \\
\hline 6 & National Institute of Medical Technology & Dhaka & 24 & Newlab Institute of Medical Technology & Dhaka \\
\hline 7 & Institute of Medical Technology & Dhaka & 25 & $\begin{array}{l}\text { Islami Bank Institute of Health } \\
\text { Technology }\end{array}$ & Rajshahi \\
\hline 8 & $\begin{array}{l}\text { Chittagong Institute of Medical } \\
\text { Technology }\end{array}$ & Chittagong & 26 & Psyche Institute of Health Technology & Bogra \\
\hline 9 & $\begin{array}{l}\text { Healthways Institute of Medical } \\
\text { Technology }\end{array}$ & Bogra & 27 & $\begin{array}{l}\text { Institute of British Colombia Medical } \\
\text { Technology }\end{array}$ & Dhaka \\
\hline 10 & $\begin{array}{l}\text { Professor Sohrab Uddin Institute of } \\
\text { Medical Technology }\end{array}$ & Tangail & 28 & $\begin{array}{l}\text { Jaypurhat Institute of Medical } \\
\text { Technology }\end{array}$ & Jaypurhat \\
\hline 11 & $\begin{array}{l}\text { Prime Institute of Science and Medical } \\
\text { Technology }\end{array}$ & Rangpur & 29 & $\begin{array}{l}\text { Institute of Medical and Dental } \\
\text { Technology }\end{array}$ & Tangail \\
\hline 12 & Trauma Institute of Medical Technology & Dhaka & 30 & CSSR Institute of Medical Technology & Chittagong \\
\hline 13 & $\begin{array}{l}\text { Bangladesh Institute of Medical } \\
\text { Technology }\end{array}$ & Pabna & 31 & $\begin{array}{l}\text { Greenview Institute of } \\
\text { HealthTechnology }\end{array}$ & Dhaka \\
\hline
\end{tabular}

of BTEB. Without having any collaboration with BTEB, the PCB started providing diploma in pharmacy courses. Pharmacy education have not been clearly defined if it is technical or not.. Challenging the PCB, the BTEB has also lately started working in the area of Pharmacy Education via its affiliated private institutions. "The quality of course curricula and capacity of these institutes are questionable" [6]. It has created a significant amount of heated debates amongst different ministries and professional bodies. This is not only a threat to quality but also to the identity crisis.

\section{Drug manufacturing and distribution}

Development of the pharmaceutical industry started slowly after eleven years of independence in 1982 by promulgation of the "Drug Control Act". As at 2000, two hundred and Ten licensed allopathic drug-manufacturing units existed. Only one hundred seventy three of these were active in production; the others folded up either due to difficult business challenges or non-compliance to good manufacturing practice or drug laws. As one of the fastest growing industries, the total size of the 'pharma-market'in Bangladesh was estimated to be BDT $28,416^{1}$ Million in 2004.

${ }^{1}$ One US \$ equivalent to seventy eight Bangladesh taka (BDT)
With an annual growth rate of more than $10 \%$, the sector is now heading towards selfdependency in meeting local demand thereby reducing import. The sector has started exporting a to few developing countries.

Currently, imported drugs in Bangladesh mainly comprise of anti-cancer drugs, vaccines for viral diseases and hormones. The Pharmaceutical industry has now become the second highest contributor to the national revenue income after garments, and "it is the largest white-collar intensive employment sector of the country". Although, foreign and franchise-based industries are in operation, local companies are in majority having a market share of $80 \%$. There are about 450 generics registered in Bangladesh. Of these, 117 are in the essential drug list. The total number of brands /items that are registered in Bangladesh is currently estimated to be 5,300 , while the total number of dosage forms and strengths are 8,300.There were 1,495 wholesale and about 37,700 retail drug license holders in 2000. This figure has increased dramatically.

\section{DEMAND VS SUPPLY: SCOPE FOR COMMUNITY PHARMACISTS}

In developing countries, there is a shortfall of skilled professionals. This is probably due to budgetary constraints that prevent the educational sector from being able to supply the 
adequate number of required professionals. The few professionals that graduate from the universities are usually underpaid due to economic instability in their home countries hence to migrate oversases hence shortages of healthcare professionals like pharmacists still exists $[14,15]$.

While there is supply of pharmacy graduates required for drug manufacturing, the scenario in hospitals and clinics is disappointing because of existing policies where those with diploma qualification work. After four decades of independence, health care management in government is still significantly poor $[17,18,19$, 20]. Only physicians and nurses work in the hospitals as caregivers. A health care team in other countries usually consists of a physician, a pharmacist and a nurse. Evidence shows that graduate pharmacists are not serving in the government hospitals in Bangladesh as health care providers for proper drugs and diseases management [7].

A pharmacy diploma graduate heads the pharmacy department available for patients in the public hospitals. This staff just dispenses and distributes the medicines. Due to the poor and incomplete health management system in Bangladesh, prescription errors are very common and many patients suffer from severe complications and even die. There is no clinical pharmacist in any public hospital in Bangladesh who can identify and resolve drug therapy problems associated with different diseases.

Recently, some private hospitals in Bangladesh have employed graduate pharmacists in their out-patients pharmacy departments. However, pharmacists are not working in the in-patient department for proper drug management and monitoring can therefore not be done. At present, about 30-40 pharmacists are working in private hospitals and in some high profile retail pharmacies located in Dhaka. However, most of the private hospitals have been operating without employing a pharmacist [7]. The problem of nonemployment of pharmacists in pharmaceutical retail outlets is probably due to the lack of regulation that prescribes minimum standards [8]. Many drug therapy problems that may lead to increase in length of hospital stay, resistance development, death and injury will remain unresolved. This increases the cost of health care with its associated socio-economic problems for families.

Full-time academics from public universities are employed on part-time basis by private universities. The private sector produce pharmacists at a lower unit cost since they lack the type of infrastructures that public institutions have. It will be beneficial for the healthcare industry if collaboration can exist between employers of pharmaceutical manpower and the educational institutions. The universities will train pharmacists for employers of labour based on their specific manpower needs while the industry will provide support for infrastructural development. At present, this kind of arrangement does not exist.

Intelligent students in public sector are forced to study subjects that they did not apply for because of the rigid selection process and limited seats. On the other hand, not-so-intelligent students in private universities are pursuing higher degrees in pharmacy which are beyond their intellectual capacity. Bright students who can pay high fees are now in private schools because they have been rejected by the public universities and will end up not being properly trained because of the limited laboratory equipment and infrastructure in the private institutions.

Because of the 'market driven' demand created by the 'existing state public policy', both the public and private sectors target the same group of students by delivering similar types of rogrammes and degrees. Moreover, there is no legal obligation for the employees to have a proper qualification in pharmacy in order to work for hospitals, clinics and retail pharmacies. Government should determine a minimum qualification in Pharmacy required for a particular role. In order to improve standards, the role of both public and private universities should be clearly defined as the basis of the infrastructures available for training a particular skill level for the pharmaceutical sector. For the pharmacy graduates of Bangladesh universities to be competent globally, it is important that any minimum standards that will be prescribed takes into account what is currently the gold standard for pharmacy practice in the country of nations.

\section{Limitation}

The collection of information from various sources and conduct of interviews used in developing this paper was not systematic and organized in any scientific pattern. However, this report is synthesized from the testimonies of those who regulate the profession and that of those who have experienced pharmacy education first hand in Bangladesh, hence inaccuracies will be minimal. 


\section{CONCLUSION}

The state of pharmacy education in Bangladesh is currently not satisfactory. Co-ordination and regulation is poor and lacks planning to meet skilled manpower needs of community and hospital pharmacy practice.

The law and relationships between different government agencies responsible for pharmacy education should be re-examined such that specific roles can be defined within the context of Bangladesh socio-economic developmental interests. This process should ensure that minimum standards are set for both the establishment of pharmacy schools and for those admitted into the practice of the profession as it is done in other countries

\section{REFERENCES}

1. Ahmed SI, Hassali MAA. The controversy of Pharm. D. degree (letter). American J Pharm Edu. 2008; 72(3): Article 71.

2. Alam GM. Impact of Private Higher Education on Bangladeshi Education System: An Investigation of Education Policy. Saarbrücker, Germany, VDM Verlag Publishing; 2008.

3. Alam GM. Can governance and regulatory control ensure private higher education as business or public goods in Bangladesh? Afr. J. Bus. Manage, 2009b; 3(12): 890-906.

4. Alam GM, Khalifa MTB. The impact of introducing a business marketing approach to education: a study on private HE in Bangladesh. Afr. J. Bus. Manage 2009; 3(9): 463-474

5. Alam GM, Haque KE, Khalifa MTB, Siraj SB, Ghan MFBA. The role of agriculture education and training on agriculture economics and national development of Bangladesh. Afr. J. Agric. Res. 2009; 4(12): 1334-1350.

6. Alam GM, Hoque KE, Rout GK, Priyadarshani $N$. Who gains from EFA-State business of education or private higher education business in developing nations? A study to understand the policy impact in Bangladesh. Afr. J. Bus. Manage, 2010a; 4(5): 770-789.

7. Alam GM, Khalifa MTB, Shahjamal MM. Return from education system in Bangladesh: an investigation on comparative flashback scenario. Afr. J. Bus. Manage 2009a; 3(10): 567-575.
8. Alam GM. The Role of Science and Technology Education at Network Age Population for Sustainable Development of Bangladesh through Human Resource Advancement. Sci. Res. Essays 2009; 4(11): 1260-1270.

9. Mazid MA, Rashid MA. Pharmacy Education and Career Opportunities for Pharmacists in Bangladesh. Bangladesh Pharmaceutical Journal. 2011; 14(1): 1-9.

10. Rahman S, Ahmed MU, Khuda B, Ahmed S. Can Medicine-sellers in Pharmacies Meet the Needs of STD Clients? Observations from an Urban Area of Bangladesh, 1999 (Accessed August 9, 2013, at https://centre.icddrb.org/images/wp127.pdf).

11. University Grants Commission of Bangladesh (UGC). Annual Report. Dhaka, Bangladesh, UGC, 2010.

12. Chowdhury AKA. Pharmacy education in Bangladesh: past, present and future. BAPA Journal, 2007; 8: 10-14.

13. World Bank. Bangladesh: Promoting Higher Growth and Human Development. A World Bank Country Study. Washington DC, USA, 1987.

14. United Nations Development Programme (UNDP). Human Development Report. New York, USA, UNDP Press, 2002.

15. Sen B, Acharya S. Health and poverty in Bangladesh. World Health. 1997; 5: 28-9.

16. Abdelwahab SA, Al Sunosi UYR, Bulgiba A, Hatim A and Alahmar $A$. Smoking Cessation Efforts in Special Population: A Review of Research on Muslim Countries and Communities. Int. J. Pharmacol, 2013; 9 (2): 98-107.

17. Jiang QSX, Yu FDM, and Zhang S. Adverse Drug Reactions and Pattern Use of Cephalosporins: A Retrospective Review of Hospitalized Patients During 5 Years. Int. J. Pharmacol; 20139 (1): 66-73.

18. Bashed M.A., Alam GM, Kabir MA and Al-Amin AQ. Male Infertility in Bangladesh: What Serve Better-Pharmacological Help or Awareness Programme? Int. J. Pharmacol; 20128 (8): 687-694.

19. Vijayakumar TM, Sathyavati $D$, Subhashini $T$, Grandhi, S and Dhanaraju, MD. Assessment of Prescribing Trends and Rationality of Drug Prescribing. Int. J. Pharmacol; 20117 (1): 140143.

20. Ansari, JA and Inamdar NN The Promise of Traditional Medicines. Int. J. Pharmacol; 2010 6 (6): 808-812. 